\title{
Reflections on international normative change
}

$\mathrm{T}$ HE NORMATIVE CONNECTION between the UN and intra-state conflicts is not static. It is a matter of continuous redefinition and reinterpretation as can be usefully observed in the context of intra-state peacekeeping environments. One of our contentions in this study is that, in the space of just three decades - that is, from the early 1960s to the early 1990 s - the normative basis of UN peacekeeping in intra-state conflicts has evolved unevenly but appreciably in terms of both objectives and authority, with the shift in the pattern of prescribed functions emerging as one important indicator of this change.

Objectives were conceptualised here with reference to four key principles enshrined in the UN Charter, namely peace and security, state sovereignty, human rights and socio-economic development. Authority, on the other hand, was conceptualised in a four-dimensional way, to encompass the depth and breadth of peacekeeping functions, the requirement of consent, the UN's normative competence to make judgements, and the implementation of decisions. Within this conceptual framework, we developed an analysis of the collective expectations of the international community, focusing specifically on the objectives and authority of the UN in relation to intra-state peacekeeping environments in the two specified time periods.

As a first step, we established that both international normative prescriptions and the UN as actor had evolved under the influence of structural changes in world politics. The early 1960s and the early 1990s were critical thresholds in the post-1945 period, each with its own particular power configuration and corresponding ideational framework. Against this backdrop, we analysed how the general political and normative complexion of the post1945 world order had evolved in the context of intra-state peacekeeping.

The focus, especially in our detailed case studies, was on three interrelated considerations, the elaboration of which would pave the way for a comprehensive examination of normative change. For each specified time period, we 
set out to discern the differences separating the positions of various actors, and their impact on the normative basis of the UN's involvement in intra-state conflicts. We then sought to identify the relationship between the most influential normative positions and the interests that they reflected and often, but not always, reinforced. In other words, we attempted to characterise the nexus between interests and normative preferences. Finally, we tried to explore how major normative differences were reconciled, resolved, or somehow synthesised. In other words we subjected to careful scrutiny the crystallisation of the dominant normative prescriptions surrounding the UN's role in peacekeeping environments. Building on these three considerations, we examined how the normative basis of intra-state peacekeeping had changed from the early 1960s to the early 1990s.

On the available evidence, our analysis suggests that the UN's main objective, namely maintenance of 'international peace and security' lost little of its salience over time, although the way that objective was interpreted may have undergone considerable change. Objectives were conceived more and more in terms of an integrated approach to the UN's peace and security function. An implicit distinction was in due course drawn between the 'external' and 'internal' dimensions of state sovereignty. In the absence of 'external' threats, protection of 'external' sovereignty was progressively downplayed as an objective in favour of promotion of 'internal' sovereignty, which in turn became closely interlinked with promotion of human rights and socioeconomic development. ${ }^{1}$

On the authority front, too, a significant change could be detected. Developments with respect to all four dimensions of authority had a cumulative effect which became especially striking in the rising intensity of UN involvement in intra-state conflicts. While in the 1960s authority for the management of intra-state conflicts was deemed to rest directly with the parties to the conflict, the tendency in the 1990s was for that authority to be located with increasing frequency and acceptance in the UN. In the quest for a more independent mechanism of conflict management, the UN revealed itself as the most plausible option. Though motivations varied considerably in each case, regional and global players, and to a lesser degree intra-state parties, came to view the UN as uniquely placed to assume this role. The UN, in other words, was now seen as a plausible though temporary and partial political authority, capable, in normative terms, of overseeing, and seeking compliance with, the 'rules of the game'.

\section{Normative change in a historical structural context}

Having reached this stage in our analysis, it may be useful to reflect a little more closely on an elusive but unavoidable question. If it is true to argue that 
the objectives and authority ascribed to the UN acquired new meaning, what might this imply for the evolution of the international political landscape from the 1960s to the 1990s and perhaps beyond? After all, discerning continuities and discontinuities is one thing, fully grasping its logic quite another, and understanding its wider implications another still. It is at this stage that our other contention becomes clearer, namely that the normative change we have detected can be usefully understood in terms of a complex interaction between material, ideational and institutional factors in a historical structural setting, which has a good deal of forward momentum.

The Congo was in many ways the Somalia of its time. 'Never again another Congo' prevailed as the international motto for nearly thirty years. How might this be explained? In contrast to the dominant preoccupation in the peacekeeping literature, issues of 'success' and 'failure' have not been the primary focus of this study. Yet one cannot help but ask in the light of our analysis, whether the international reluctance to create space for UN peacekeeping in the aftermath of the Congo operation stemmed from ONUC's 'failure' to accomplish its mission. Despite all the difficulties and complexities in the theatre of conflict, judged by several criteria, ONUC was by no means an unmitigated failure, especially in the light of such relatively recent disasters as Bosnia, Rwanda and Sierra Leone. Thanks largely to active UN involvement, the internal conflict did not escalate to the point of international (regional or global) confrontation. A modicum of internal law and order was established; the political process in the country was revitalised; and eventually, in accordance with the dominant wish of the international community, the Congo's territorial integrity was preserved. What is more, ONUC's casualties were citizens neither of the United States nor of another great power - all the more reason, one might have thought, for an expansive approach to UN peacekeeping to ensue.

Instead, a 'Congo syndrome' emerged, that was clearly visible in Cyprus and elsewhere. In Cyprus, France and the Soviet Union did not favour UN intervention. It is arguable that the United States, too, would have been less than enthusiastic about UN peacekeeping, had the crisis developed between an American and a Soviet proxy rather than between two parties with special ties to American regional allies. In a sense, Cyprus was a 'backward' step so far as enlargement of political space for UN action was concerned, as indeed it was for the redefinition of its normative basis. The terms of UN involvement were carefully designed, camouflaged in convenient ambiguity, to ensure that the Congo episode would not repeat itself. In this sense, ONUC may be regarded as an isolated phenomenon. The Congo mission did not usher in a new 'phase'. There was nothing quite like it either immediately before or immediately after, or indeed for some time to come.

In a sense, what happened in the Congo was a testing of the geopolitical 
power play in all its dimensions - material, ideational and institutional. Prior to the ONUC episode, the full extent of the structural contradictions and tensions impinging on peacekeeping had not yet been revealed. In the Congo episode, the Soviet Union initially favoured the 'central' government, though it would subsequently change its attitude to one of favouring the 'legitimate' government. The United States initially favoured its (neo)colonialist allies, but over time adopted a position closer to that favoured by the Third World. All other actors, to varying degrees, had to redefine their stance. These contradictory preferences were not, however, merely the policy 'choices' of rational actors. Neither did they reflect primarily processes of social learning and internalisation in the wake of prior normative commitments. Rather, they developed under the influence of the prevailing structural constraints. The tensions and contradictions inherent in the structural configuration were perhaps most visible in the contortions of the Secretaries-General of the time, who had enormous difficulty in reconciling 'peacekeeping principles' with the prevailing material and ideational configurations in the peacekeeping environment. Inescapably, the normative 'resolution' that emerged in such an inhospitable environment was merely momentary, certainly in no sense definitive or even indicative of a possible new trend.

In the space of three decades, the international system experienced a number of structural shifts, if not outright transformation, in both material and ideational terms. Several contradictions inherent in the existing historical structure manifested themselves in ways conducive to change. Just to mention one example, the adoption of human rights discourse in the international arena, as we have seen, was partly the result of the East-West antagonism, with each side trying to gain leverage over the opponent by appealing to a wider audience. Nor was the North-South axis of conflict without its own contradictions. Unity and disunity went hand in hand in the geographically expanded South.

Perhaps the most important dialectic common to both axes of conflict was the relationship between state and non-state players. As Falk reminds us in reference to the Third World's socio-economic aspirations, which can be characterised as a unifying tendency in the South, "even without resistance from the centers of capital in the North, there were problems with this essentially statist vision of global economic reform ... tending to stabilise inhumane governance at the state level'.2 Although such contradictions had not fully played themselves out, they were strong enough by the late 1980 s to have a substantial impact on the structure of the international system. Again, Falk is illuminating here. Two historical conditions in the post-Cold War years characterised the period of 'transition to geogovernance'. ${ }^{3}$ The first was the removal of 'any pattern of strategic antagonism in the North' (mainly the Cold War), whereby the North was left in control of the management of global 
power and resources and as 'the source of ideological cohesion'. Second, and for our purposes more important, was 'the seeming appropriation by the US government of the United Nations, especially the Security Council, as an instrument of geopolitical legitimation and public mobilization, at least in some situations'. This seeming appropriation involved, as Falk immediately adds, 'a reshaping of geopolitics, but also ... a path toward geogovernance'.${ }^{4}$ In other words, an intentional (or, given that it operates under structural constraints, 'presumably' intentional) policy choice may well have led to unintended outcomes and consequences. Put still differently, the treatment of the UN as an instrument may have led to the development of the UN as actor in its own right. It may have gone even further and brought about the beginnings of a 're-institutionalisation' of the UN.

In the context of our analysis the same idea may be usefully, and perhaps more graphically, expressed with the benefit of Cox's triangular framework. In a nutshell, the changing geopolitical material configurations (understood primarily in terms of economic, political and military power) were accompanied, though not necessarily with the same rhythm or at the same speed, by an ideational change as observable in the relative ascendancy of such values as human rights and socio-economic development on the international platform. For a long time, however, the institutional corner of the triangle (for our purposes, the UN as 'institution') lagged behind. At a critical historical juncture, in the early 1990s, the changing material and ideational attributes combined to form a 'hegemonic' historical structure which heavily influenced international normative preferences, yet still lacked a fully corresponding institutional framework. ${ }^{5}$

\section{'Institutional' implications of 'normative' change?}

In this study we have problematised the UN as 'actor' rather than 'institution', keeping in mind that the attributes of the UN as actor are closely connected to the UN as institution - to a higher degree than is the identity of any other international actor. Few observers would disagree that the behaviour of the UN is obviously and necessarily constrained and facilitated by the Charter. We have already argued, in addition, that the job description of the UN as actor whether in intra-state peacekeeping or any other sphere of activity - is influenced by the material and ideational characteristics of the international environment in which it operates. More specifically, the role and conduct of the UN (in a sense, the UN's 'identity' as actor) is constrained and facilitated by the international community's interpretations (ideas/values) of the Charter (institutionalised ideas/values) within a given power configuration (material capabilities).

The change we have detected in the normative basis of intra-state 
peacekeeping is, then, but one manifestation of the international community's evolving interpretation of the UN as 'institution'. 6 At its inception, the UN stood as a symbol for collective security and inter-governmental regulation. The impression we gain from the intra-state peacekeeping since the early 1990s is, however, rather different. Apart from what the UN actually does or does not do, and how it does or does not do it, there is little doubt that it tries to fulfil a different set of collective expectations - not necessarily expectations that represent a complete break with the past, but expectations which nonetheless represent significant modification, adaptation and development. Ideas of collective security and inter-governmental regulation are still very much part and parcel of the UN's identity. Yet, at least implicitly, there is more that is expected of the UN, not least the notion that it is an active participant in the task of governance at different levels. By the mid-1990s, the UN, it seems, was seen as an agent not only of global regulation, but of regional coordination and even local supervision. Increasingly it came to be seen as a source of authority that could legitimately pronounce on the standards which governance had to observe - a trend implicit in the very notion of 'good governance'.

Thus far the argument has proceeded by way of conceptual abstraction. But what of the evidence to be gleaned from more recent developments? In Kosovo, the conflict which had escalated after the abolition the Province's autonomous status eventually prompted a NATO bombing campaign against the new Yugoslavia between March and June 1999. The assessment, planning and implementation stages of NATO's intervention occurred with negligible reference to the Security Council. ${ }^{7}$ It would seem, at least at first sight, as if, in the wake of the unipolar moment, a US-led coalition had effectively sidestepped the UN and tried to impose its unilateral decision. Yet is this all that happened? In the immediate aftermath, the UN was called upon to play a role in domestic governance. Why else would the UN be asked to coordinate the post-bombing interim administration in Kosovo ${ }^{8}$

In East Timor, following the UN-organised ballot and the subsequent eruption of violence, the Security Council authorised an Australian-led multinational force (INTERFET) to restore peace and security and to facilitate humanitarian assistance operations. ${ }^{9}$ In this episode, Australia no doubt pursued its regional foreign policy (with the blessing of the United States), while a transnational coalition of civil society organisations pursued either their human rights programmes or their anti-Indonesian political agendas. The fact remains that it was the UN that was called upon to fill the political space created by Indonesia's withdrawal. ${ }^{10}$ The legitimacy of action, which Australia and others needed, was acquired through UN authorisation and involvement. Equally striking is the often overlooked fact that the UN successfully pressed Indonesia, certainly not the weakest of states, to give its consent to a coercive Chapter VII operation in what it still regarded as 'its' territory. ${ }^{11}$ 
From one vantage point, then, our study confirms the obvious, namely that international actors, especially major powers, continued in the early 1990s to treat the UN as an instrument - a policy option - in the pursuit of interests, just as they did in the early 1960 s. $^{12}$ Not surprisingly, UN peacekeeping, the UN activity which perhaps best symbolises the 'UN as actor' (with its blue helmets, flag, equipment, headquarters and relatively distinctive mode of action), was called upon by a loose coalition of western/northern states to perform a diverse range of activities in a geographically dispersed set of southern countries. The UN was given the task of dealing with 'complex emergencies' in a number of 'failed states'. Arguably, the 'complex emergencies' and 'failed states' rhetoric was itself part and parcel of the emerging hegemonic power configuration of the 1990s, and reflected as much a particular (hegemonic) 'image of reality' as the 'reality in itself'. ${ }^{13}$

Be that as it may, the key point is that international actors continued to treat the UN, and UN peacekeeping, as an instrument of policy that could be utilised at a suitable historical moment to achieve desired outcomes. Taken at face value this observation may not seem particularly startling. What is striking, however, is that the UN gradually became the almost 'automatic' option for an international community needing to respond to multiple intra-state conflicts. More frequent application of the UN peacekeeping mechanism - let alone the changes that peacekeeping has undergone - was no doubt one manifestation of this. Rightly or wrongly, the UN was now viewed as the organisation best equipped to manage political and societal breakdown in conflict-torn states. To put it simply but not inaccurately, whenever something went drastically wrong within a state, the UN was somehow expected to be actively engaged, indeed to take the lead, in the search for a solution. The UN's interventionism, its deepening involvement in the business of governance, was met with increasing acceptance, even encouragement. The authority assigned to the UN and the integrated objectives it was expected to pursue did not end with Namibia and Cambodia. Nor, for that matter, with Bosnia and Rwanda. Kosovo and East Timor also pointed to the changing collective expectations of the UN. Do we detect a trend here? It would as yet be foolhardy to draw categorical conclusions in the affirmative - especially given the nebulous scenery created by September 11 . What can be said is that high expectations placed in the UN have thus far survived the enormous difficulties in its path, ${ }^{14}$ which is not to say that the UN's evolving authority has ever matched its evolving purpose.

Nevertheless, when ECOWAS announced that it would withdraw its peacekeeping force from Sierra Leone, the Security Council was subjected to mounting pressure for the authorisation of an expanded UN presence there. ${ }^{15}$ Whether deemed successful or not, the UN Assistance Mission to Sierra Leone (UNAMSIL) was certainly authorised under a Chapter VII 
mandate to facilitate, among others, humanitarian relief efforts, support free and fair elections, and more generally strengthen the political process. The second Congo mission (MONUC), too, had a Chapter VII mandate with a clear emphasis on human rights and humanitarianism. Notwithstanding the slowing pace of UN action, the normative expectations that crystallised in the early 1990s do not appear to be losing momentum. If indeed the specified three decades have seen material and ideational change, with institutional change lagging behind, it may well be the case that the international community is still grappling with the task of constructing an institutional framework compatible with the new material and ideational configurations.

In responding to crises of peace and security (understood broadly to encompass man-made humanitarian catastrophes) the international community has a wide spectrum of choices and methods at its disposal. Yet this does not change the fact that it is actually confronted with two major sensible options - especially with respect to intra-state conflicts: to intervene effectively or not to intervene at all. The latter option, though at times tempting, may itself prove rather costly given the long-term ramifications for security and stability, in both political and socio-economic terms, locally as much as regionally and even globally. Effective intervention, however, raises the awkward question: whose intervention is likely to be effective? In the first place, unilateral intervention, at least since Vietnam, has proven politically difficult to execute for western states, especially the United States, unless immediately recognisable vital interests are at stake as is exemplified by the post-September 11 'war on terrorism'. Moreover, even the most determined unilateral intervention falls short of being truly effective, if for no other reason than its narrowly defined focus on immediate outcomes of the operation and its almost guaranteed failure to address multidimensional long-term consequences of the intervention. The only other option remains 'multilateral' intervention, although the multilateralism in question may be frequently limited in scope/geography and far from universal. ${ }^{16}$ For the moment such intervention appears feasible given that the South's capacity to oppose western hegemony remains limited and that the internal contradictions within the West/North have yet to offset the dominant unipolar power configuration.

Still, the question remains: what 'kind' of multilateral response? Who or which entity is best suited to manage conflicts, and, eventually, guarantee a degree of international stability? The UN readily suggests itself as the plausible option. On the one hand, it gives legitimacy to the policy preferences of major powers which somehow coexist. On the other, it makes it possible for each major stake-holder in any given conflict to contribute, however marginally, to the decision-making process. It is not surprising, then, that the late $1990 \mathrm{~s}$ 
witnessed a continuation of the emerging international mindset that has guided the peacekeeping formula in Angola, Cambodia and elsewhere in the immediate aftermath of the Cold War.

There is, of course, no guarantee that this 'trend' will continue, or that it is immune to tensions and contradictions, especially given that it is subject to structural constraints and opportunities. Nor is its desirability beyond criticism. Yet the evidence suggests that the UN is increasingly called upon to 'govern' what might otherwise become ungoverned or ungovernable political space - whether at the local, regional or global levels or at their intersection. The UN's evolving governance function, however, does not fit neatly into traditional frameworks of governance. Rather it assumes complex territorial as well as non-territorial qualities, and proceeds on the basis of painfully difficult normative 'resolutions' or, at least, 'syntheses' that constantly interact with changing power configurations on the world stage. Placed in a historical structural setting, this may be suggestive of the slow but continuing institutionalisation of new ideas, values, expectations, and patterns of behaviour. The contemporary world may be in the process of creating a new mosaic of complex, fluid and interlinked forms of governance, in which the UN is admittedly only one, though uniquely placed, actor which reflects, influences, and, above all, gradually re-institutionalises the changing international normative landscape.

\section{NOTES}

1 The Secretary-General would declare that there is complementarity between the processes related to the Agenda for Development and the Agenda for Peace ... Development cannot be attained in the absence of peace and security or in the absence of respect for all human rights and fundamental freedoms.' See B. Boutros-Ghali, An Agenda for Development: With Related UN Documents (New York: United Nations, 1995), paras 3-4.

2 Falk, On Humane Governance, p. 28.

3 Falk, On Humane Governance, pp. 85-6.

4 Falk, On Humane Governance, p. 86; emphasis added.

5 From this perspective, the latest proposals for a new and/or expanded Security Council may be interpreted as the international community's search for appropriate re-institutionalisation.

6 This in turn may be a manifestation of the evolving multilateralism, understood as a 'deep organising principle' rather than an institution per se: see Knight, A Changing United Nations, p. 38.

7 As was the case with the Iraqi situation, however, the Kosovo operation took place in the context of several UN resolutions dealing with the Kosovo crisis, including SC Resolutions 1160, 1199, 1203.

8 Following the withdrawal of FRY security forces from Kosovo, and subsequent suspension of NATO air operations, the Security Council established an international civilian administration in Kosovo (UNMIK), which has been vested with all legislative, executive and judicial powers in the territory it administers: see SC Resolution 1244 dated 10 June 1999. 


\section{Reflections on international normative change}

9 SC Resolution 1264 of 15 September 1999.

10 SC Resolution 1272 of 25 October 1999 would authorise an integrated, multi-dimensional peacekeeping operation fully responsible for the administration of East Timor during its transition to independence: UNTAET.

11 Following the visit of a Security Council mission to Jakarta and Dili in September 1999, Indonesia agreed to accept the international community's assistance offer. The ensuing SC Resolution 1264 of 15 September reaffirmed 'respect for the sovereignty and territorial integrity of Indonesia', not of East Timor: see preambular para. 8. Furthermore, the resolution made reference to 'peaceful and orderly transfer of authority in East Timor [from Indonesia] to the United Nations': see operative para. 8.

12 Whether the 'interests' in question are those as would be defined by hardline 'realists' or those that may have emerged from a process of mutual constitution as would be defined by 'constructivists' need not detain us here. Similary, the interests may well be national or sectional.

13 An influential IGO (the OECD) and an influential NGO (Oxfam) alike could be seen to adopt the 'complex emergency' rhetoric; see, respectively, OECD, Guidance for Evaluating Humanitarian Assistance in Complex Emergencies (London: Overseas Development Institute and OECD Development Assistance Commitee, 1999), and Oxfam International, Improving the UN's Response to Complex Emergencies (Washington, DC: Position Paper, November 1997). For 'failed states', see A. A. Mazrui, 'The failed state and political collapse in Africa', in O. A. Otunnu and M. W. Doyle (eds), Peacemaking and Peacekeeping for the New Century (Lanham, MD: Rowman \& Littlefield, 1998).

14 Consider the UN's changing role vis-à-vis Afghanistan immediately before, during and after the fall of the Taliban regime in the aftermath of September 11.

15 For instance, Kofi Annan pressed for the authorisation of a sizeable force.

16 For an emphasis on this understanding of multilateralism, see in general J. G. Ruggie (ed.), Multilateralism Matters: The Theory and Praxis of An Institutional Form (New York: Columbia University Press, 1993), and in particular Friedrich Kratochwil's contribution to the same volume. 